\title{
TØR DU BE OM RÅD PÅ JOBB?
}

For noen kan det være vanskelig å be om hjelp og råd i en vanskelig arbeidssituasjon. Grunnen til det kan være at man er redd for å bli oppfattet som dum eller mindre kompetent.

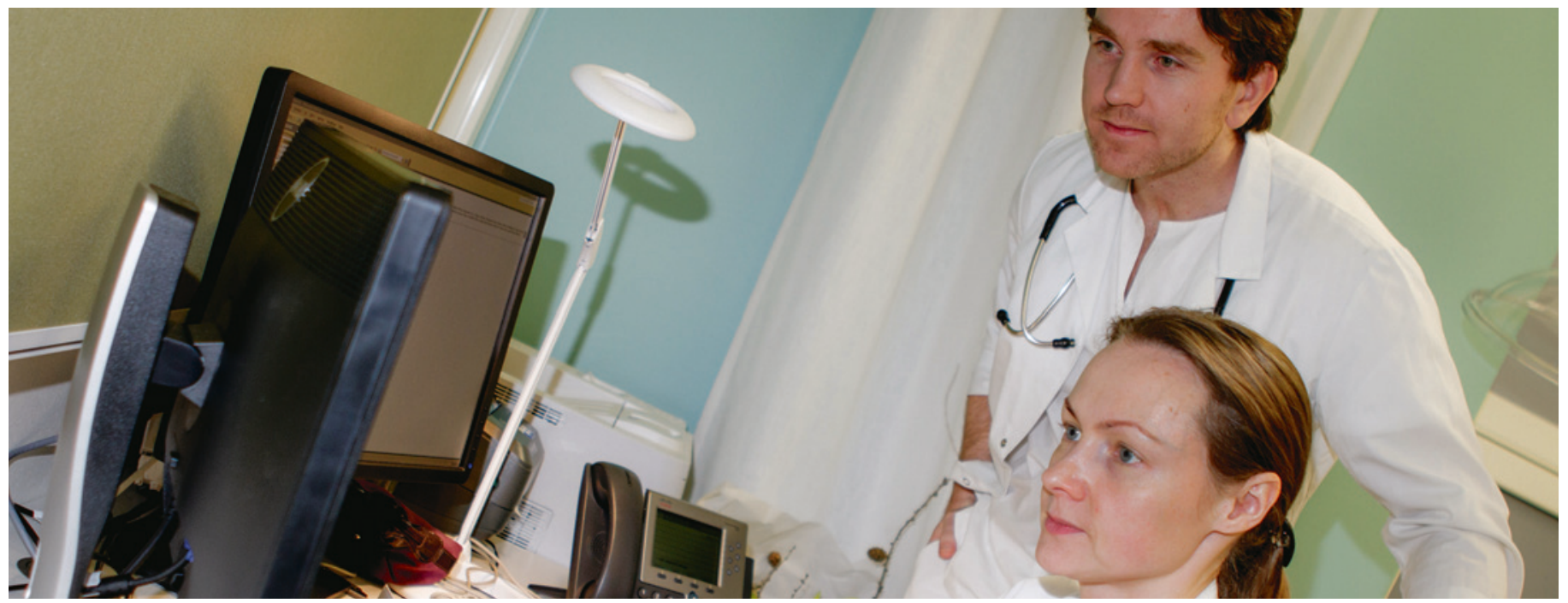

Kolleger ved St. Olavs hospital. Foto: Ole Kristian Losvik

Ifølge studier gjennomført av forskeren Allison Brooks ved Harvard Business School (1) viser det seg at de som tør å be om råd, fremstår som mer kompetente enn de som ikke gjør det. Folk liker å bli bedt om råd - det får oss til å føle oss smarte og styrker selvtilliten vår. Den som blir spurt, vil få et bedre inntrykk av den som ber om hjelp eller råd.

Og man gir inntrykk av å være mer kompetent dersom man ber eksperter om råd eller hjelp heller enn å snakke med ikkeeksperter om problemstillingen, viser studiene.

\section{En uholdbar risiko på sykehus}

Øyvind Kvalnes, førsteamanuensis ved Institutt for ledelse og organisasjon ved Handelshøyskolen BI, har diskutert temaet med folk i helsevesenet (2).

«Ved et sykehus fortalte de at sykepleiere og leger hadde helt ulik kultur for å snakke om personlig usikkerhet. Det kunne blant annet gi seg utslag i hvordan nyansatte oppforte seg,» skriver han i en kommentar på BIs nettsider.

«En ny lege som ble invitert inn i en for ham ukjent og fremmed prosedyre ville, i motsetning til sykepleiere, late som om han var fortrolig med å jobbe på denne måten. Det satt vesentlig lenger inne hos en lege enn hos en sykepleier å innrømme egen usikkerhet. For pasienter skaper dette en helt uholdbar risiko for feilbehandling. Leger trenger å ha mot til å be om råd og assistanse når de er usikre,» skriver Kvalnes.

\section{Forskjellig klima på arbeidsplassen}

På alle arbeidsplasser er det forskjellig klima når det kommer til det å ytre seg. Det kan ha å gjøre med hvordan man vanligvis roser hverandre og hvordan ytringer tas imot.

«Personer som skjuler at de er usikre og hjelpeløse, kan utgjøre en vesentlig risiko i arbeidslivet. De kvier seg for å be om bistand fra andre, og vil ordne opp selv. Noe annet vil være å tape ansikt. Med denne innstillingen kan de skape farlige situasjoner,» skriver Kvalnes.

\section{Elisabeth Jacobsen}

Tidsskriftet

\section{Litteratur}

1. Brooks AW. Assistant Professor of Business Administration. www.hbs.edu/faculty/Pages/profile. aspx?facld=684820\&faclnfo=pub (17.9.2014).

2. Kvalnes $\varnothing$. Trenger du hjelp? www.bi.no/bizreview/ artikler/trenger-du-hjelp-/ (17.9.2014).
«Det satt vesentlig lenger inne hos en lege enn hos en sykepleier å innrømme egen usikkerhet» 